\title{
EFFICACY OF TULSI AND NEEM LEAVES EXTRACT IN BROILER PRODUCTION
}

\author{
S. Khatun, M. Mostofa*, F. Alom, J. Uddin, M. N. Alam, and N.F. Moitry \\ Department of Pharmacology, Faculty of Veterinary science, Bangladesh Agricultural University, Mymensingh- \\ 2202, Bangladesh.
}

\begin{abstract}
The efficacy of tulsi (Ocimum sactum) and neem (Azadirachta indica) leaves extract as a growth promoter were studied in broiler. A total of 40 day-old broiler chicks were purchased from Kazi hatchery and after three days of acclimatization the chicks were randomly divided into four groups $(\mathrm{n}=10)$. No vaccination schedule was practiced and no antibiotic was added in ration of group A, B, C, and D respectively. Group A served control without any supplements while group B, C and D were supplemented with combination of tulsi and neem extract @ $1 \mathrm{ml}, 2 \mathrm{ml}$ and $3 \mathrm{ml} /$ liter of drinking water. Live body weight gain was recorded weekly up to $6^{\text {th }}$ weeks and hematological studies were performed at $21^{\text {st }}$ and $42^{\text {nd }}$ day of experiments. At the end of $42^{\text {nd }}$ day of experiment final body weight of group A, B, C and D were $1561 \pm 12.10 \mathrm{~g}, 1698 \pm 12.87 \mathrm{~g}, 1608 \pm 12.04 \mathrm{~g}$ and $1763 \pm 13.28 \mathrm{~g}$, respectively. The birds of group D utilized their feed more efficiently among the treatment groups $(\mathrm{p}<0.05)$. The net body weight gain were, $1533 \pm 11.98 \mathrm{~g}, 1443 \pm 11.32 \mathrm{~g}$ and $1588 \pm 12.10 \mathrm{~g}$ in treated groups compared to control group $(1393 \pm 11.07 \mathrm{~g})$ and total net profit per broiler was 19.08, 40.10, 20.68 and 45.07 Taka, respectively. Hematological parameterss (TEC, PCV, Hb and ESR) were not significantly changed among the treated and control group suggesting no side effects of herbal extracts in broiler. It can be concluded that tulsi and neem extract is economic and safe in broiler production.
\end{abstract}

Key words: Tulsi, neem, growth promoter, broiler.

\section{INTRODUCTION}

The poultry production systems have led to marked increase in the production of poultry meat and eggs throughout the world (Armstrong, 1986). It has triggered the discovery and widespread use of a number of "feed additives". The term feed additive is applied in a broad sense, to all products other than those commonly called feedstuffs, which could be added to the ration with the purpose of obtaining some special effects. The main objective of adding feed additives is to boost animal performance by increasing their growth rate, better-feed conversion efficiency, greater livability and lowered mortality in poultry birds. These feed additives are termed as "growth promoters" and often called as non-nutrient feed additives (Singh and Panda, 1992). Many synthetic drugs and growth promoters are supplemented to the broilers to effect rapid growth, but their use have shown many disadvantages like high cost, adverse side-effect on health of birds and long residual properties etc. Growth promoters are chemical and biological substances, which are added to livestock food with the aim to improve the growth of chickens in fattening, improve the utilization of food and in this way realize better production and financial results. European Commission banned four commonly used feed antibiotics: monensin sodium, salinomycin sodium, avilamycin, flavophospholipol. The banning of antibiotic growth promoter (AGP) will affect the poultry and livestock industry . To minimize the loss in growth, there is a need to find alternative to AGP. There are a number of non-therapeutic alternatives such as enzymes, inorganic acids, probiotics, prebiotics and herbs (Banerjee, 1998). Since ancient times herbs and their essentials have been known for their varying degree of antimicrobial activity (Juven et al., 1994). More recently, medicinal plants extracts were developed and proposed for use in food as natural antimicrobials (Hsieh and Mau 2001) Neem and tulsi has attracted worldwide prominence due to its vast range of medicinal properties like antibacterial, antiviral, antifungal, antiprotozoal, hepatoprotective and various other properties without showing any adverse effects (Kale et al., 2003). Also, neem and tulsi promotes growth and feed efficiency of birds because of their antibacterial properties (Prasannabalaji et al., 2012).

Neem and tulsi leaves extract has immunostimulant effect that activates the cell mediated immune response and therefore, creates an enhanced response to any future challenges occurred by disease organisms. So, the feeding neem and tulsi leaves to immunosuppressed birds increased their humoral and cell mediate immune responses (Sadekar et al., 1998). Neem and tulsi leaves contain a vast array of chemically diverse and biologically active ingredients (Devakumar and Suktt, 1993). Low dose of neem leave extract have an inhibitory action on wide spectrum of microorganisms (Talwar et al., 1997) and immuonomodulator actions that induce cellular immune reaction (Devakumar and Suktt, 1993). 


\section{S. Khatun and others}

Also, Craig (1999) stated that several herbs could help providing some protection against bacteria and stimulate the immune system. However, in Bangladesh little work has been done on the effect of plants extracts on body weight and performance in poultry. The present study was, therefore, conducted to determine the effect of tulsi and neem leaves extracts in broiler diets as a possible alternative to antibiotic feed additives.

\section{MATERIALS AND METHODS \\ Collection and preparation of leave extracts}

Tulsi and neem leave were selected for effectiveness as growth promoter on poultry. Mature and disease free tulsi and neem leave were collected from BAU campus. For the preparation of dust, the leaves were dried in sun for 10 days and followed by oven at $55-60^{\circ} \mathrm{C}$ for 2 days. The dried leaves were pulverized with a blender. A 25 (unit) mesh diameter sieve was used to obtain the fine dust, the dust was preserved in airtight plastic container until they were directly used for screening and preparation of water extract. Ten (10) gram each leave powder was added to $80 \mathrm{ml}$ of distilled water and was shaking overnight at room temperature, filtered and distilled water was added up to $100 \mathrm{ml}$ to make $10 \%$ extract. (Mollah et al., 2012)

\section{Experimental design}

A total of 40, day-old broiler chicks were purchased from Kazi hatchery and were allowed to acclimatize for 3 days at the experimental shed. The initial body weights of assigned chickens were taken with digital weight machine and were recorded. The experiment was conducted according to the completely randomized design. Birds were divided into 4 equal groups (A, B, C \& D). Group A was considered as untreated control fed on commercial feed only, group B, C and D were supplemented with tulsi and neem at the dose rate of $1 \mathrm{ml} /$ liter, 2 $\mathrm{ml} /$ liter and $3 \mathrm{ml} /$ liter drinking water respectively in addition to commercial feed for 42 day of experiments.

Data were collected on initial body weight, weekly body weight gain and weekly feed consumption. The data collected were utilized to calculate weekly growth rate, efficiency of feed utilization and mortality percentage. The data collected on the production cost of broiler were used to find out the commercial viability of the herbal growth promoter. Cost of production of the broiler in each group was calculated on per $\mathrm{kg}$ basis to work out the economics of production of the birds for each group. At the end of the experiment, three birds from each group were picked up randomly and slaughtered for their dressing percentage and giblet weight (heart, liver, gizzard \& spleen). The weight of pancreas was also recorded. The slaughtered birds were scalded by immuring them into the water at temperature ranging from $180-190^{\circ} \mathrm{F}$ (Jull, 1976). After that, the birds were manually plucked by hanging them on shackles by their feet. The weight of each carcass was recorded and dressing percentage was calculated on the basis of dressed meat including giblets and skin. After evisceration, the heart, liver, gizzard, spleen and pancreas of the slaughtered birds were taken out and weighed for their absolute weight. The data thus obtained were used for the calculation of (a) dressing percentage (\%) (Dress weight of bird/Live weight of bird) $\times$ 100) (b) relative weight of (i) heart (ii) liver (iii) gizzard (iv) spleen and (v) pancreas. After evisceration, relative weights $(\mathrm{g})$ [(weight of organ/live body weight) X 100] of various internal organs such as liver, heart, gizzard, spleen and pancreas of the slaughtered bird were recorded. The data thus collected regarding weight gain, feed consumption, feed conversion ratio, dressing percentage and relative weights of heart, gizzard, liver, spleen and pancreas were subjected to the analysis.

\section{Hematological parameters}

Blood samples were collected from wing vein of chicken of both control and treated groups at 21 st and $42^{\text {nd }}$ day. The following parameters were observed: (a) total erythrocyte count (TEC), (b) hemoglobin content (Hb), (c) packed cell volume (PCV) and (d) erythrocyte sedimentation rate (ESR) with standard methods as described by Lamberg and Rothstein (1977).

Post-mortem examination was carried out to see any lesions. Three chickens from each group were slaughtered to see if there were any pathological changes occurred. There was no significant pathological change found in any internal organs of the chickens of treated groups.

\section{Statistical analysis}

The data were analyzed statistically between control and treated groups by student's t- test.

\section{RESULTS AND DISCUSSION}

In control group (Group A) initial live wt. 168 $\pm 8.54 \mathrm{gm}$, final live weight was. $1561 \pm 12.10 \mathrm{gm}$ and weight gain $1393 \pm 11.07 \mathrm{gm}$ and Feed conversion ratio (FCR) was 2.25. In all treatment groups supplementation of herbal extracts 1-3 ml/litre drinking water resulted in significant $(\mathrm{p}<0.05)$ increase in mean live weight $($ Table 1$)$. 
Similarly, Mollah et al. (2012) reported significant increase in the live weight of broilers compared with control group. Statistical analysis of the data did not show any difference between the relative spleen weight of the birds of different feeding groups using ration with or without supplementation of tulsi and neem leave extract (Table 2). Supplementation of neem and tulsi leave extract (NTL) in the treatment caused improvement in the feed efficiency as compared to that of control group. Similarly, Nath et al. (2012), Mollah et al. (2012) reported increase in feed efficiency in neem and tulsi fed groups, which is in agreement with the findings of the present study.

Table 1. Live weight, weight gain, feed consumption and feed conversion ratio of broilers fed different levels of tulsi and neem leaves extract from 1 to 6 weeks of age

\begin{tabular}{|lcccc|}
\hline Variables & Control & \multicolumn{3}{c|}{ Treatment } \\
\hline & $\mathrm{A}(\mathrm{n}=10)$ & $\mathrm{B}(\mathrm{n}=10)$ & $\mathrm{C}(\mathrm{n}=10)$ & $\mathrm{D}(\mathrm{n}=10)$ \\
& Control & (Tulsi and neem) & (Tulsi and neem) & (Tulsi and neem) \\
Initial live weight $(\mathrm{g})$ on $7^{\text {th }}$ day & $168 \pm 8.54$ & $166 \pm 7.95$ & $2 \mathrm{ml} /$ litre & $3 \mathrm{ml} /$ litre \\
Final live weight $(\mathrm{g})$ on $42^{\text {nd }}$ day & $1561^{\mathrm{a}} \pm 12.10$ & $1698^{\mathrm{b}} \pm 12.87$ & $1608^{\mathrm{b}} \pm 1.49$ & $166 \pm 7.04$ \\
Weight gain $(\mathrm{g})$ & $1393^{\mathrm{a}} \pm 11.07$ & $1533^{\mathrm{b}} \pm 11.98$ & $1443^{\mathrm{b}} \pm 11.32$ & $1763^{\mathrm{b}} \pm 13.28^{*}$ \\
Feed consumption $(\mathrm{g})$ & $3140^{\mathrm{a}}$ & $3050^{\mathrm{b}}$ & $3140^{\mathrm{a}}$ & $1588^{\mathrm{b}} \pm 12.10^{*}$ \\
FCR & 2.25 & 1.99 & 2.19 & $3035^{\mathrm{b} *}$ \\
\hline
\end{tabular}

Mean values within the same row, which have different superscripts, were significantly different $(\mathrm{p}<0.05)$.

Table 2. Dressing percentages, relative giblet weight (heart, gizzard, liver and spleen) and pancreas weight of broilers fed different levels of tulsi and neem leaves extract from 1-6 weeks of age

\begin{tabular}{|lcccc|}
\hline \multicolumn{1}{|c}{ Variables } & Control & Treatment & D \\
\hline & A & B & C & 64.58 \\
Dressing percentage (\%) & 64.49 & 63.94 & 63.20 & 0.45 \\
Relative heart weight $(\mathrm{g})$ & 0.44 & 0.45 & 0.48 & 1.49 \\
Relative gizzard weight $(\mathrm{g})$ & 1.43 & 1.62 & 1.59 & 2.58 \\
Relative liver weight $(\mathrm{g})$ & 2.59 & 2.57 & 2.56 & 0.11 \\
Relative spleen weight $(\mathrm{g})$ & 0.10 & 0.10 & 0.12 & 0.24 \\
Relative pancreas weight $(\mathrm{g})$ & 0.26 & 0.25 & 0.25 & \\
\hline
\end{tabular}

Relative weight $(\mathrm{g})=$ Weight of organ/ Live body weight of bird X 100, Dressing \%= Dress weight of bird/Live weight of bird X 100

Birds supplemented with tulsi and neem leave extract had higher body weight, weekly gain in weight, feed consumption and feed efficiency. These results may be due to antimicrobial and anti-protozoal properties (Kale et al., 2003) of tulsi and neem leaves, which help to reduce the microbial load of birds and improved the feed consumption and feed efficiency of the birds. It is concluded that supplementation 1-3 $\mathrm{ml}$ of tulsi and neem leave extract/kg poultry ration of treatment groups caused significant increase in live body weight And improvement in weekly gain in weight and feed efficiency as compared to that of control group of poultry. Our results are in line with those reported by Siddig and Abdelati (2001) who carried out a research work in broiler fed rations containing turmeric and cloves showing higher weight gain. In our study, the use of neem and tulsi leave extract showed more increase in live weight of the birds as compared to control, which is also in agreement with the findings of Samanta and Dey (1991), who concluded that powdered cinnamon may be incorporated as a growth promoter in the ration of Japanese quails. Better feed conversion ratio of the broiler using rations supplemented with neem and tulsi leave extract may be attributed to the antibacterial properties of these supplements, which resulted in better absorption of the nutrients present in the gut and finely leading to improvement in feed conversion ratio of the rations. This study has revealed that NTL extract had no significant effect on the hematological parameters (Table 4). This finding, however, does not agree with Nagalakshmi et al. (1996) and Gowda et al. (1998) who reported that bitter principles of medicinal plants possess a strong influence on hematological traits particularly PCV and $\mathrm{Hb}$ of subjects, depending on their nutritional status. 


\section{S. Khatun and others}

Table 3. Economics of broiler production kept under different treatment groups from 1-day old to 6 weeks of age

\begin{tabular}{|lcccc|}
\hline Description & $\mathrm{A}$ & $\mathrm{B}$ & $\mathrm{C}$ & $\mathrm{D}$ \\
\hline Cost/chick (Taka) & 60.00 & 60.00 & 60.00 & 60.00 \\
Average feed consumed (Kg)/chicks & 3.140 & 3.050 & 3.140 & 3.035 \\
Feed price/kg (Taka) & 38.00 & 38.00 & 38.00 & 38.00 \\
Cost of herbal growth promoters (Taka) & 0.00 & 2.00 & 4.00 & 6.00 \\
Feed cost (Taka.) & 119.32 & 115.90 & 119.32 & 115.33 \\
Miscellaneous ( Taka) & 20.00 & 20.00 & 20.00 & 20.00 \\
Total cost/broiler (Taka.) & 199.32 & 197.90 & 203.32 & 201.33 \\
Average live weight (Kg) & 1.560 & 1.700 & 1.600 & $1.760^{*}$ \\
Sale price/Kg live wt. (Taka.) & 140.00 & 140.00 & 140.00 & 140.00 \\
Sale price/broiler (Taka) & 218.40 & 238.00 & 224.00 & 246.40 \\
Net profit/broiler (Taka.) & 19.08 & 40.10 & 20.68 & 45.07 \\
Profit/ Kg live weight (Taka) & 12.23 & 23.59 & 12.93 & 25.61 \\
\hline
\end{tabular}

Supplementation with neem and tulsi extract was more profitable than control group (Table 3 ) but the difference was not significant $(\mathrm{p}>0.05)$.

Table 4: Effect of tulsi and neem leaves extract on hematological parameter of broiler

\begin{tabular}{|c|c|c|c|c|c|}
\hline Neem and tulsi & & Treatment & Mean & Std. error Mean & $P$ value \\
\hline \multirow{8}{*}{$21^{\text {st }}$ day } & \multirow{2}{*}{$\mathrm{RBC}(\mathrm{mm} 3)$} & Tulsi+neem & 197.30 & 7.52 & \multirow{2}{*}{0.046} \\
\hline & & Control & 191.33 & 6.35 & \\
\hline & $\mathrm{Hb}(\mathrm{g} \%)$ & Tulsi+neem & 6.46 & 0.06 & \multirow{2}{*}{0.02} \\
\hline & \multirow{3}{*}{$\operatorname{PCV}(\%)$} & Control & 6.00 & 0.13 & \\
\hline & & Tulsi+neem & 19.00 & 0.59 & \multirow{2}{*}{0.420} \\
\hline & & Control & 16.31 & 0.87 & \\
\hline & \multirow[t]{2}{*}{ ESR $\mathrm{mm}$ in $1^{\text {st }}$ hour } & Tulsi+neem & 8.65 & 0.87 & \multirow{2}{*}{0.025} \\
\hline & & Control & 10.66 & 0.85 & \\
\hline Neem and tulsi & & Treatment & Mean & Std. error Mean & $\mathrm{P}$ value \\
\hline \multirow{8}{*}{42 day } & \multirow{2}{*}{$\mathrm{RBC}(\mathrm{mm} 3)$} & Tulsi+neem & 297.66 & 12.11 & \multirow[t]{2}{*}{0.242} \\
\hline & & Control & 248.60 & 13.86 & \\
\hline & \multirow[t]{2}{*}{$\mathrm{Hb}(\mathrm{g} \%)$} & Tulsi+neem & 7.62 & 0.19 & \multirow{2}{*}{0.052} \\
\hline & & Control & 6.90 & 0.25 & \\
\hline & \multirow[t]{2}{*}{$\operatorname{PCV}(\%)$} & Tulsi+neem & 20.70 & 0.33 & \multirow{2}{*}{0.225} \\
\hline & & Control & 17.00 & 0.59 & \\
\hline & \multirow[t]{2}{*}{ ESR $\mathrm{mm}$ in $1^{\mathrm{st}}$ hour } & Tulsi+neem & 4.00 & 1.00 & \multirow{2}{*}{0.234} \\
\hline & & Control & 7.00 & 0.59 & \\
\hline
\end{tabular}

This discrepancy could be explained by two ways. Firstly, the duration of the experimental period could have an influence on the hematological parameters as we know that the lifespan of RBC is approximately120 days. Our experiment was limited for a short period of time (42 days) in comparison to other's work. Secondly, neem and tulsi leave extract extracts having no significant effect on the hematological parameters in broiler may suggest that these herbs have no harmful or side effects, particularly on hematological parameters.

\section{CONCLUSION}

From the findings of the present study it can be concluded that supplementation with neem and tulsi leave extract @ 1-3 ml/L drinking water causes significant increase in live body weight and improvement in weekly weight gain and feed efficiency as compared to that of control group of broiler. 
Thus, neem and tulsi leave extract supplementation in the broiler rations may be useful for the safe, economical and efficient production of broiler and this formulation could be used as an alternative to commercial growth promoters.

\section{REFERENCES}

1. Armstrong DG (1986). Gut active growth promoters. In: Control and manipulation of animal growth. Eds. By Buttery PJ, Lindsay DB and Haynes NB pp. 21-37.

2. Banerjee, L. K. (1998). 12. Floral status of Buxa tiger reserve, West Bengal. Plant Diversity in the Tiger Reserves of India 71.

3. Craig WJ (1999). Health-promoting properties of common herbs. American Journal of Clinical Nutrition 70 (3): 491-499.

4. Devakumar C and Suktt DV (1993). Chemistry, In: Randhawa NS \& Parmar BS (eds), neem research and development. 63-96.

5. Gowda SK (1998). Neem (Azadirachta indica) kernel meal in the diet of White Leghorn layers. British poultry science 39(5): 648-652.

6. Hsieh PC and Mau JL (2001). Antimicrobial effect of various combinations of plant extracts. Food Microbiology 18: 35-43.

7. Jull AA (1976). Poultry Husbandry, 3rd Edn. Tata Mcgraw Hill Publishing Company Ltd., New Delhi, India.

8. Juven BJ, Kanner J, Schved F and Weisslowicz H (1994). Factors that interact with the antibacterial action of thyme essential oil and its active constituents. Journal of Applied Bacteriology 76: 626-631.

9. Kale BP, Kothekar MA, Tayade HP, Jaju JB and Mateenuddin M (2003). Effect of aqueous extract of Azadirachta indica leaves on hepatotoxicity induced by antitubercular drugs in rats. Indian Journal of Pharmacology 35(3): 177-180.

10. Lamberg SL and Rothstein R (1977). Laboratory Manual of Hematology and Urinalysis. Avi. Publishing Company, Inc, West Port Connecticut, USA.

11. Mollah MR, Rahman MM, Akter F and Mostofa M (2012). Effects of nishyinda, black pepper and Cinamon extract as growth promoter in broiler. The Bangladesh Veterinarian 29 (2): 69-77.

12. Nagalakshmi D, Sastry VRB, Agrawal DK, Katiyar RC and Verma SVS (1996). Performance of broiler chicks fed on alkali $\square$ treated neem (Azadirachta indica) kernel cake as a protein supplement. British Poultry Science 37(4): 809-818.

13. Nath DD, Rahman MM, Akter F and Mostofa M (2012). Effects of Tulsi, Black pepper and Cloves extract as a growth promoterr in broiler. Bangladesh Journal of Veterinary Medicine 10 ( 1\& 2) : 33-39.

14. Prasannabalaji N, Muralitharan G, Sivanandan RN, Kumaran S and Pugazhvendan SR (2012). Antibacterial activities of some Indian traditional plant extracts. Asian Pacific Journal of Tropical Disease 2: S291-S295.

15. Sadekar RD, Kolte AY, Barmase BS and Desai VF (1998). Immunopotentiating effects of Azadiracta indica (Neem) dry leaves extract in broiler, naturally infected with IBD virus. Indian Journal of Experimental Biology 36(11): 1151-1153.

16. Samanta AR and Dey A (1991). Effect of feeding garlic (A. sativum Linn.) as a growth promoter in Japanese quails (C. coturnix japonica) and its influence on dressing parameter. Indian Journal of Poultry Science 26: $142-145$.

17. Siddig RM and Abdelati K (2001). Effect of dietary vitamin A and N. sativa on broiler chick's performance. In Proceeding: 10th International Conference of Association for TropicalVeterinary Medicine and Livestock. Community and Environment, Copenhagen, Denmark.

18. Singh KS and Panda B (1992). Feed additives. In: Poultry nutrition. 2nd ed. Kalyani publ. Delhi, pp. 134143 .

19. Talwar GPP, Raguvanshi RAS, Mukherjee and S Shah (1997). Plant immunomodulators for termination of unwanted pregnancy and contraception and reproductive health. Immunology and Cell Biology 75 (2): 190192. 